\title{
Efektivitas intervensi psikoedukasi keluarga terhadap kekambuhan pasien skizofrenia
}

\author{
Rini Gusya Liza ${ }^{1}$, Bahagia Loebis², Vita Camellia ${ }^{2}$ \\ 1. Bagian Ilmu Kedokteran Jiwa, Fakultas Kedokteran Universitas Andalas/RSUP Dr. M. Djamil, \\ Padang; 2. Program Studi Ilmu Kedokteran Jiwa, Fakultas Kedokteran Universitas Sumatera Utara
}

Korespondensi: Rini Gusya Liza; email: rinigusya@yahoo.com

\begin{abstract}
Abstrak
Psikoedukasi keluarga telah terbukti menjadi intervensi yang efektif untuk pasien dengan skizofrenia dan anggota keluarga mereka. Tujuan: Untuk menilai pengaruh intervensi psikoedukasi keluarga terhadap pengetahuan, pemberdayaan anggota keluarga serta kekambuhan pasien skizofrenia. Metode: Penelitian randomized controlled trial dengan desain true experimental pre post test with control group. Jumlah subjek adalah 49 orang yang terdiri dari kelompok I (24 orang) adalah kelompok caregiver yang memperoleh terapi farmakologi dan terapi psikoedukasi keluarga dengan 3 sesi. Kelompok II (25 orang) adalah kelompok kontrol yaitu caregiver yang hanya mendapatkan terapi farmakologi saja. Studi ini dilakukan selama 6 bulan mulai dari Juni 2014 sampai dengan Desember 2014. Pada akhir penelitian dilakukan penilaian angka kekambuhan pada pasien skizofrenia. Hasil: Didapatkan persentase kekambuhan pasien skizofrenia pada kelompok caregiver yang diberikan psikoedukasi adalah 2,04\% dan persentase kekambuhan pada kelompok caregiver yang tidak diberikan edukasi adalah $12,24 \%$ dan didapatkan perbedaan yang bermakna angka kekambuhan/relap antara kelompok intervensi dengan kelompok kontrol. Simpulan: Intervensi psikoedukasi keluarga sangat membantu dalam meningkatkan pengetahuan tentang skizofrenia dan meningkatkan pemberdayaan caregiver serta secara tidak langsung menurunkan angka kekambuhan pada pasien skizofrenia.
\end{abstract}

Kata kunci: psikoedukasi keluarga; caregiver; pasien skizofrenia

\section{Abstract}

Family psychoeducation has proven to be an effective intervention for patients with schizophrenia and their family members. Objectives: To assess the influence of family psychoeducation intervention on knowledge, empowerment of family members as well as the relapse of schizophrenic patients. Methods: The study was a randomized controlled trial with a true experimental design pre post-test with control group. The number of subjects was 49 people consisting of group I (24 people) are a group of caregivers who obtain pharmacological therapy and family psychoeducation therapy with 3 sessions. Group II (25 people) was the control group caregivers who just get pharmacological therapy alone. The study was conducted over 6 months from June 2014 to December 2014. At the end of the study the relapse rate is assessed. Results: The recurrence of schizophrenic patients in the caregiver group given psychoeducation was $2.04 \%$ and the recurrence in the caregiver group that was not given education was $12.24 \%$. At the end of the study found significant differences KASI and FES scores between the intervention group and the control group $(p<0.05)$ and found significant differences in rate of relapse between the intervention group and control group. Conclusions: Family psychoeducation intervention is helpful in increasing knowledge about schizophrenia and increase caregiver empowerment and indirectly reduce the relapse rate in patients with schizophrenic.

Keywords: family psychoeducation; caregiver; schizophrenic patients 


\section{PENDAHULUAN}

Skizofrenia adalah gangguan otak berat berlangsung seumur hidup. Gangguan ini menimbulkan kesulitan bagi orang tersebut untuk memahami perbedaan antara pengalaman nyata dan tidak nyata, berpikir logis, memiliki respon emosional yang sesuai dengan budaya, dan untuk berperilaku tepat dalam situasi sosial. Tidak hanya pasien dengan skizofrenia yang sangat menderita karena penyakit ini, tetapi juga anggota keluarga mereka. ${ }^{1}$

Jauh sebelum didiagnosis skizofrenia, keluarga dari seseorang dengan gangguan tersebut mungkin mulai merasa stres. Prodromal atau tanda-tanda awal skizofrenia dapat muncul beberapa tahun sebelum diagnosis ditegakkan. Anggota keluarga mungkin mulai melihat perubahan relatif perilaku mereka. Perubahan perilaku dapat menyebabkan banyak kecemasan, kekhawatiran, atau rasa bersalah bagi anggota keluarga dari seseorang dengan skizofrenia. ${ }^{2}$

Keluarga yang merawat pasien melaporkan besarnya beban sehubungan dengan perawatan keluarganya yang menderita gangguan mental. Mereka tidak memiliki pengetahuan dan keahlian yang perlu untuk menghadapi tanggung jawab perawatan pasien. Oleh sebab itu umumnya terjadi kekambuhan dan rawat inap kembali. ${ }^{3}$

Sejak tahun 1970 psikoedukasi telah menjadi bentuk terapi dan rehabilitasi yang disusun baik untuk orang yang menderita skizofrenia dan keluarga mereka. Psikoedukasi didefinisikan sebagai penggunaan metode, teknik dan program edukasi dalam rangka memfasilitasi remisi atau mengurangi efek penyakit atau disabilitas. Terapi psikoedukasi tidak hanya mencakup memberikan pengetahuan. Selama sesi terapi dikembangkan strategi yang meningkatkan kemampuan dan meningkatkan fungsi pasien skizofrenia. Sesi-sesi psikoedukasi memberikan pengetahuan yang berhubungan dengan perjalanan penyakit individu dan penyembuhan dan pada efek yang melibatkan kognitif dan emosional pasien. ${ }^{4}$

Psikoedukasi keluarga telah terbukti menjadi intervensi yang efektif untuk pasien dengan skizofrenia dan anggota keluarga mereka. ${ }^{1}$ Psikoedukasi dikenal untuk mengurangi tingkat kekambuhan dan rawat inap di beberapa gangguan kejiwaan seperti skizofrenia, depresi dan gangguan bipolar. Dengan demikian, biaya kesehatan mental yang signifikan dan penderitaan manusia yang substansial dapat dihindari dengan partisipasi pasien dan anggota keluarga pada intervensi yang murah ini. ${ }^{5}$

Bukti dari meta-analisis menunjukkan bahwa psikoedukasi untuk pasien skizofrenia dan keluarga mereka dapat mengurangi angka relap dan mempunyai efek positif pada pasien dan keluarga seperti mengurangi beban keluarga. Intervensi yang lebih dari 3 bulan lebih efektif dibandingkan intervensi singkat. ${ }^{6}$

Penggunaan intervensi psikoedukasi 
keluarga untuk terapi pasien skizofrenia di poliklinik Rumah Sakit Jiwa Pemprov Sumatera Utara masih sangat terbatas, pasien sebahagian besar hanya diberikan terapi psikofarmaka, tanpa pemberian terapi psikososial seperti psikoterapi ataupun terapi yang melibatkan keluarga. Oleh sebab itu peneliti tertarik untuk melakukan suatu penelitian intervensi psikoedukasi keluarga di rumah sakit ini.

\section{METODE}

Penelitian ini adalah penelitian randomized controlled trial dengan desain true experimental pre post test with control group dengan intervensi psikoedukasi keluarga. Kelompok I adalah kelompok anggota keluarga yang memperoleh terapi farmakologi dan terapi psikoedukasi keluarga dengan 3 sesi dan kelompok II adalah kelompok kontrol yaitu anggota keluarga yang hanya mendapatkan terapi farmakologi saja. Penelitian dilakukan di Instalasi rawat jalan RSJ Daerah Pemprov Sumatera Utara dan Gedung Pendidikan RSJ Daerah Pemprov Sumatera Utara pada bulan Maret-Desember 2014.

Populasi dan subjek penelitian adalah keluarga pasien skizofrenia yang berperan sebagai caregiver (perawat pasien) yang datang ke Poli Psikiatri RSJ Daerah Pemprov Sumatera Utara pada JuniDesember 2014 dan memenuhi kriteria inklusi. Cara pengambilan sampel dengan non probability sampling jenis consecutive sampling. Alokasi subjek menggunakan simple random sampling. Didapatkan besar sampel masing-masing kelompok sebanyak 25 orang dengan total 50 orang. Keluarga pasien skizofrenia yang memenuhi kriteria inklusi diberikan informed consent untuk mengikuti sesisesi psikoedukasi keluarga. Sesi-sesi psikoedukasi keluarga antara lain Joining Session (sesi bergabung), Educational workshops (lokakarya pendidikan) dan ongoing psychoeducation sessions (sesi psikoedukasi berkelanjutan). Sesi bergabung terdiri dari sesi bergabung I, II, dan III, yang masing-masing dilakukan satu kali pertemuan selama satu jam setiap sepuluh hari. Lama dari sesi bergabung ini lebih kurang satu bulan. Pada masingmasing sesi bergabung dilakukan tugastugas sesuai dengan buku pedoman psikoedukasi keluarga. ${ }^{7}$

Pada lokakarya pendidikan dilakukan seminar satu hari dengan mengundang semua kelompok anggota kelompok I. Adapun materi lokakarya adalah Penjelasan tentang pengertian, penyebab dan pengobatan skizofrenia, dampak skizofrenia pada keluarga, penjelasan tentang psikoedukasi keluarga dan diskusi. Sesi psikoedukasi berkelanjutan ini dilakukan minimal satu kali sebulan selama 5 bulan. Sesi ini diusahakan dalam format kelompok multi-family dimana dihadiri oleh beberapa anggota keluarga dan pasien, bila tidak memungkinkan di lakukan dalam format keluarga tunggal. Kegiatan-kegiatan yang dilakukan pada sesi ini antara lain; sosialisasi, mengidentifikasi isu-isu saat ini, melakukan pemecahan masalah 
terstruktur (menetapkan masalah, memberikan solusi-solusi, mendiskusikan keuntungan dan kerugian masing-masing solusi, memilih solusi terbaik dan membentuk rencana aksi). ${ }^{7}$

Pada akhir penelitian diberikan kuesioner penilaian jumlah kekambuhan pada kedua kelompok. Dan hasilnya dianalisis dengan menggunakan uji $t$-dependent, uji $t$ independent, uji chi-square program SPPS (bila memenuhi syarat) dan sebelumnya dilakukan uji normalitas data. ${ }^{8,9}$

\section{HASIL DAN PEMBAHASAN}

Pada akhir penelitian terdapat 24 keluarga caregiver dan pasien skizofrenia pada kelompok intervensi dan 25 keluarga caregiver dan pasien skizofrenia pada kelompok kontrol.

Dari gambar 1 dapat ditunjukkan, pada awal penelitian terdapat 50 orang keluarga caregiver pasien skizofrenia rawat jalan di BLUD RSJ Provinsi Sumatera Utara yang terdiri dari 25 orang kelompok intervensi dan 25 orang kelompok kontrol yang ikut serta dalam penelitian ini. Kemudian dilakukan sesi awal yaitu joining session (sesi bergabung) I, II dan III pada 25 orang subjek penelitian kelompok intervensi. Setelah itu dilakukan suatu educational workshop (lokakarya pendidikan) yang dilaksanakan pada tanggal 2 September 2014 pada 25 subjek tersebut, dan dilanjutkan dengan ongoing psychoeducational session (sesi psikoedukasi berkelanjutan).
Pada bulan ketiga penelitian terdapat tiga orang subjek penelitian yang drop-out (dikeluarkan) dari penelitian, dari ketiga subjek tersebut satu orang pasien meninggal dunia, subjek kedua pindah ke kota lain, dan satu orang lagi tidak bisa dihubungi dan sudah tidak pernah datang ke instalasi rawat jalan RSJ Provinsi Sumatera Utara. Karena masih cukup waktu dan sumber daya kemudian dilakukan penambahan 3 orang subjek penelitian pada bulan tersebut dengan melakukan terlebih dahulu joining session (sesi bergabung) dan educational workshop (lokakarya pendidikan). Pada bulan kelima terdapat lagi satu orang subjek penelitian yang drop-out karena tak bersedia melanjutkan sesi psikoedukasi karena subjek memiliki pekerjaan yang tidak bisa lagi mengantar pasien pergi kontrol berobat. Karena tidak cukup waktu penelitian maka tidak dilakukan penambahan subjek penelitian.

Pada kelompok kontrol terdapat 5 orang subjek yang drop-out, dua orang subjek tidak dapat dihubungi dan tidak pernah datang kontrol, satu orang subjek sakit dan tidak bisa mengikuti sesi selanjutnya, satu orang lagi pindah kontrol ke rumah sakit lain, dan yang terakhir pasien menolak dibawa berobat jadi subjek dan pasien tidak pernah datang lagi kontrol ke instalasi rawat jalan RSJ Provinsi Sumatera Utara. Pada akhir penelitian terdapat 24 keluarga caregiver dan pasien skizofrenia pada kelompok intervensi dan 25 keluarga caregiver dan pasien skizofrenia pada kelompok kontrol. 


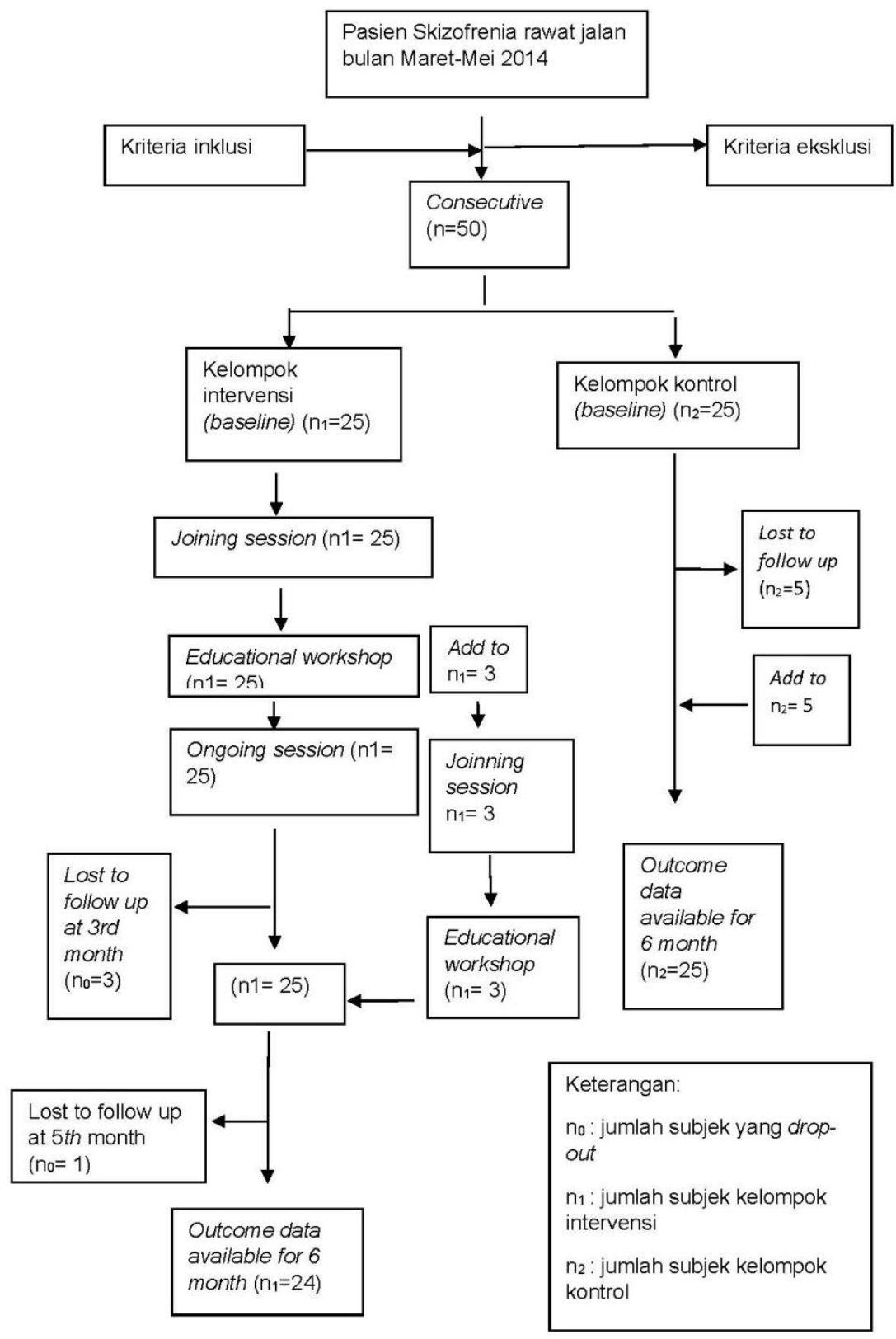

Gambar 1. Flow diagram penelitian 
Pada tabel 1 dapat dilihat usia caregiver terbanyak adalah berusia antara 45-60 tahun yaitu $58,3 \%$ pada kelompok intervensi dan $48 \%$ pada kelompok kontrol, jenis kelamin terbanyak adalah perempuan yaitu $62,5 \%$ pada kelompok intervensi dan $52 \%$ pada kelompok kontrol, status perkawinan terbanyak adalah menikah yaitu $70.8 \%$ pada kelompok intervensi dan $76 \%$ pada kelompok intervensi, sedangkan tingkat pendidikan terbanyak adalah SMA yaitu 58,3\% pada kelompok intervensi dan 56\% pada kelompok kontrol. Pada umumnya subjek bekerja yaitu $66,67 \%$ pada kelompok intervensi dan $80 \%$ pada kelompok kontrol. Keluarga yang sebagai caregiver terbanyak adalah Ibu kandung pada kelompok intervensi yaitu 37,5\% sedangkan pada kelompok kontrol adalah saudara kandung $6 \%$. Kedua kelompok ini setara dan dapat dibandingkan dimana dari uji statistik tidak didapatkan perbedaan yang bermakna baik dari klasifikasi umur, jenis kelamin, status perkawinan, tingkat pendidikan, pekerjaan dan hubungan dengan pasien skizofrenia antara kedua kelompok.

Tabel 1. Distribusi karakteristik demografi keluarga caregiver pasien skizofrenia

\begin{tabular}{|c|c|c|c|c|c|c|}
\hline \multirow{2}{*}{\multicolumn{2}{|c|}{ Karakteristik demografi }} & \multicolumn{2}{|c|}{ Kelompok Intervensi } & \multicolumn{2}{|c|}{ Kelompok Kontrol } & \multirow[t]{2}{*}{$\mathrm{p}$} \\
\hline & & $(n=24)$ & $\%$ & $(n=25)$ & $\%$ & \\
\hline \multirow[t]{4}{*}{ Usia } & $18-25$ & 2 & 8,30 & 1 & 4 & $0,930^{*}$ \\
\hline & $26-35$ & 1 & 4,20 & 6 & 24 & \\
\hline & $36-45$ & 7 & 29,20 & 6 & 24 & \\
\hline & $46-60$ & 14 & 58,30 & 12 & 48 & \\
\hline Jenis & Laki-laki & 9 & 37,50 & 12 & 48 & $0,456^{* *}$ \\
\hline kelamin & Perempuan & 15 & 62,50 & 13 & 52 & \\
\hline Status & Menikah & 17 & 70,80 & 19 & 76 & $0,171^{*}$ \\
\hline \multirow[t]{2}{*}{ perkawinan } & Belum Menikah & 4 & 16,70 & 5 & 20 & \\
\hline & Janda/Duda & 3 & 12,50 & 1 & 4 & \\
\hline \multirow[t]{3}{*}{ Pendidikan } & SMP & 2 & 8,30 & 10 & 40 & $0,981^{*}$ \\
\hline & SMA & 14 & 58,30 & 14 & 56 & \\
\hline & Perguruan tinggi & 8 & 33,30 & 1 & 4 & \\
\hline \multirow[t]{3}{*}{ Pekerjaan } & Bekerja & 16 & 66,70 & 20 & 80 & $1,00^{*}$ \\
\hline & Tidak bekerja & 7 & 29,20 & 4 & 16 & \\
\hline & Siswa/mahasiswa & 1 & 4,20 & 1 & 4 & \\
\hline \multirow{6}{*}{$\begin{array}{l}\text { Hubungan } \\
\text { dengan } \\
\text { pasien }\end{array}$} & Ayah & 3 & 12,50 & 5 & 20 & $0,988^{*}$ \\
\hline & Ibu & 9 & 37,50 & 6 & 24 & \\
\hline & Saudara kandung & 6 & 25,00 & 11 & 44 & \\
\hline & Suami/ istri & 1 & 4,20 & 0 & 0 & \\
\hline & Saudara lain & 3 & 12,50 & 1 & 4 & \\
\hline & Anak & 2 & 8,30 & 1 & 4 & \\
\hline
\end{tabular}


Pada tabel 2 didapatkan angka kekambuhan (relap) pada kelompok intervensi lebih sedikit dibandingkan kelompok kontrol yaitu 2,04\% dibandingkan $\quad 12,24 \%$. Terdapat perbedaan yang bermakna angka kekambuhan antara kelompok intervensi dengan kelompok kontrol dengan $p=0,049$ $(p<0,05)$.

Tabel 2. Perbandingan kekambuhan (relap) antara kelompok intervensi dan kelompok kontrol

\begin{tabular}{|c|c|c|c|c|c|c|c|c|}
\hline \multirow{2}{*}{ Kekambuhan } & & \multicolumn{2}{|c|}{$\begin{array}{l}\text { Kelompok } \\
\text { intervensi }\end{array}$} & \multicolumn{2}{|c|}{$\begin{array}{c}\text { Kelompok } \\
\text { Kontrol }\end{array}$} & \multicolumn{2}{|c|}{ Total } & \multirow[t]{2}{*}{$p$} \\
\hline & & $\mathrm{n}$ & (\%) & $\mathrm{n}$ & $\%$ & $n$ & $\%$ & \\
\hline & Ya & 1 & 2,04 & 6 & 12,24 & 7 & 14,30 & $0,049 *$ \\
\hline & Tidak & 23 & 46,90 & 19 & 38,80 & 42 & 85,70 & \\
\hline & & 24 & 16,30 & 25 & 93,60 & 49 & 100 & \\
\hline
\end{tabular}

Hasil penelitian menunjukkan bahwa keluarga yang mendapatkan intervensi psikoedukasi keluarga memperoleh peningkatan pengetahuan tentang skizofrenia dan peningkatan pemberdayaan keluarga yang bermakna dibanding keluarga yang tidak mendapatkan intervensi psikoedukasi keluarga, begitu juga angka kekambuhan lebih rendah secara bermakna pada pasien skizofrenia yang keluarganya mendapatkan intervensi psikoedukasi keluarga.

Pada penelitian ini didapatkan angka kekambuhan (relap) pada kelompok intervensi lebih sedikit dibandingkan kelompok kontrol yaitu 2,04\% dibandingkan $12,24 \%$. Terdapat perbedaan yang bermakna angka kekambuhan antara kelompok intervensi dengan kelompok kontrol dengan $p=0,049(p<0,05)$.

Bukti dari meta-analisis menunjukkan bahwa psikoedukasi untuk pasien skizofrenia dan keluarga mereka dapat mengurangi angka relap dan mempunyai efek positif pada pasien dan keluarga seperti mengurangi beban keluarga.
Intervensi yang lebih dari 3 bulan lebih efektif dibandingkan intervensi singkat. ${ }^{10}$

Studi yang dilakukan oleh Vickar dkk. yang memberikan psikoedukasi "Schizophrenia Treatment and Education Programs (STEPS)" kepada 57 orang pasien skizofrenia mendapatkan penurunan yang bermakna $(p=0,038)$ angka kekambuhan dan rehospitalisation pada kelompok intervensi dibandingkan kelompok kontrol. ${ }^{11}$

Studi yang dilakukan Mingyuan dkk. dengan melakukan psikoedukasi kelompok pada 3.092 pasien skizofrenia dan keluarga mereka selama 12 bulan mendapatkan hasil terapi yang lebih baik yaitu berkurangnya kekambuhan (relap) dengan perbedaan yang signifikan dibandingkan kontrol. ${ }^{12}$

Studi yang dilakukan oleh Ran dkk. memberikan psikoedukasi kepada keluarga pasien skizofrenia sekali sebulan selama 9 bulan dalam bentuk keluarga tunggal dan kelompok mendapatkan perbedaan yang bermakna angka relap antara kelompok yang diberikan intervensi psikoedukasi (16,3\%) dibandingkan 
dengan kontrol $(61,5 \%)$ dengan perbedaan yang bermakna $(p<0,05){ }^{6}$

Sedangkan studi oleh Lie dan Arthur yang melakukan psikoedukasi kepada pasien skizofrenia dan keluarganya selama 9 bulan mendapatkan rendahnya angka kekambuhan pada kelompok intervensi dibandingkan kelompok kontrol tetapi perbedaannya tidak bermakna. ${ }^{13}$

Bukti terbaru efektivitas psikoedukasi, suatu strategi terapi non-farmakologi dalam pengobatan pasien skizofrenia dan keluarga mereka dinilai dengan metaanalisis/review dan studi tunggal yang penting setelah meta-analisis diterbitkan. Ditemukan bahwa psikoedukasi untuk pasien dengan skizofrenia dan keluarga mereka dapat mengurangi tingkat kekambuhan pasien ini; intervensi keluarga jangka panjang (yaitu, dengan jangka waktu lebih dari 3 bulan) sangat membantu. Studi meta-analisis oleh Cochrane Schizophrenia Group Trials yang menilai semua studi randomized controlled trials relevan yang berfokus pada psikoedukasi pada skizofrenia dan gangguan mental berat lainnya, menyimpulkan psikoedukasi dapat mengurangi kekambuhan (relap), remission dan mendorong kepatuhan terhadap pengobatan dan juga mengurangi lama dirawat di rumah sakit selain itu efektif secara klinis dan menguntungkan secara finansial. ${ }^{14}$

Dengan mengikuti psikoedukasi keluarga anggota keluarga caregiver mendapatkan pengetahuan tentang skizofrenia terutama mengenai diagnosis, etiologi, perjalanan penyakit dan terapi, sehingga caregiver lebih memahami tentang penyakit pasien. Psikoedukasi keluarga juga melatih membentuk koping, keterampilan memecahkan masalah, memperbaiki komunikasi dan mengurangi stres. ${ }^{7}$

Pemberdayaan keluarga telah didefinisikan sebagai "suatu proses dimana keluarga mengakses pengetahuan, keterampilan dan sumber daya yang memungkinkan mereka untuk mendapatkan kontrol positif hidup mereka sendiri serta meningkatkan kualitas gaya hidup mereka". ${ }^{7}$

Hasil dari penelitian naturalistis prospektif menunjukkan bahwa keluarga yang berpartisipasi dalam program family-tofamily melaporkan adanya peningkatan pengetahuan tentang penyebab dan pengobatan penyakit mental, pemahaman yang lebih baik tentang bagaimana untuk menavigasi sistem kesehatan mental dan peningkatan kesejahteraan. Secara khusus, peserta family-to-family melaporkan pemberdayaan lebih besar secara signifikan di tingkat keluarga, masyarakat dan sistem pelayanan. Intervensi ini menunjukkan janji yang cukup besar dan memfasilitasi partisipasi dalam program psikoedukasi keluarga. ${ }^{15}$

\section{SIMPULAN}

Intervensi psikoedukasi keluarga sangat membantu dalam meningkatkan pengetahuan tentang skizofrenia dan meningkatkan pemberdayaan caregiver, secara tidak langsung menurunkan angka kekambuhan pada pasien skizofrenia. ${ }^{13}$ 


\section{DAFTAR PUSTAKA}

1. Song $Y$, Liu $D$, Chen $Y$, He G. Using focus groups to design a psychoeducation program for patients with schizophrenia and their family members. Int J Clin Exp Med. 2014; 7(1):177-185. [PubMed]

2. Veague HB. Psychological Disorders: Schizophrenia. New York: Chelsea House Publishers; 2007. p75-8.

3. Prasko J, Vrbova K, Latalova K, Mainerova B. Psychoeducation for psychosis patients. Biomed Pap Med Fac Univ Palacky Olomouc Czech Repub. 2011; 155(4):385-396. doi: 10.5507/bp.2011.008.

4. Chadzyńska M, Meder J, Charzyńska K. The participation of patients with schizophrenia in psychoeducation-the analyses from the patient's perspective. Psychiatr Pol. 2009; 43(6):693703. [PubMed]

5. Rummel-Kluge $C$, Kluge $M$, Kissling $W$. Frequency and relevance of psychoeducation in psychiatric diagnoses: Results of two surveys five years apart in German-speaking European countries. BMC Psychiatry. 2013; 13:170. doi: 10.1186/1471-244X-13-170.

6. Ran MS, Xiang MZ, Chan CLW, Leff J, Simpson P, Huang MS, et al. Effectiveness of psychoeducational intervention for rural Chinese families experiencing schizophrenia $A$ randomised controlled trial. Soc Psychiatry Psychiatr Epidemiol. 2003; 38(2):69-75. doi: 10.1007/s00127-003-0601-z.

7. Substance Abuse and Mental Health Services Administration. Family Psychoeducation: Training Frontliner Staff. Rockville, MD: Center for Mental Health Services; 2009. Diakses dari: [Link]

8. Sastroasmoro S, Ismael S. Dasar-dasar metodologi penelitian klinis. Edisi 3. Jakarta: Sagung Seto; 2008. p.166-191.

9. Dahlan MS. Statistik untuk kedokteran dan kesehatan. Edisi 5. Jakarta: Salemba Medika; 2011.

10. Rummel-Kluge $C$, Kissling W. Psychoeducation for patients with schizophrenia and their families. Expert Rev Neurother. 2008; 8(7):1067-77. doi: 10.1586/14737175.8.7.1067.

11. Vickar GM, North CS, Downs D, Marshall DL. A randomized controlled trial of a private-sector inpatient-initiated psychoeducation program for schizophrenia. Psychiatr Serv. 2009; 60(1):11720. doi: 10.1176/appi.ps.60.1.117.

12. Dixon L, Adams C, Lucksted A. Update on family psychoeducation for schizophrenia. Schizophr Bull. 2000; 26(1):5-20. doi: 10.1093/oxfordjournals.schbul.a033446.

13. Li Z, Arthur D. Family education for people with schizophrenia in Beijing,China: Randomised controlled trial. British Journal of Psychiatry, 2005; 185:339-45. doi: 10.1192/bjp.187.4.339.

14. Xia J, Merinder LB, Belgamwar MR. Psychoeducation for schizophrenia. Cochrane Database Syst Rev. 2011; 6:CD002831. doi: 10.1002/14651858.CD002831.pub2.

15. Glanville DN, Dixon L. Caregiver burden, family treatment approaches and service use in families of family of patients with schizophrenia. Isr J Psychiatry Relat Sci. 2005; 42(1):15-22. [PubMed] [Abstract/FREE Full-Text]. 